\title{
Efektivitas Pelaksanaan Supervisi Akademik Pengawas Dalam Meningkatkan Kompetensi Profesional Guru PAI SD di Kecamatan Tambun Selatan
}

\author{
Fajar Azzam Pasha Akhmad \\ Universitas Mitra Karya \\ azzampasha@gmail.com
}

\begin{abstract}
Effective strategy of academic supervision by supervisors can improve the professional competence of teachers. The limited number of supervisors and the extent of the target area are problems in the academic supervision. This study aims at knowing: 1) the effectiveness of academic supervision by supervisors to improve the professional competence of Islamic education teachers at the elementary school in District Tambun Selatan 2) the constraints faced by supervisors in conducting academic supervision, and the solution for supervisors of academic supervision that can improve the professional competence of Islamic education teachers at the elementary school in District Tambun Selatan. The results show that: 1) academic supervision conducted by supervisors in Islamic education is effective to improve the profesional competence of Islamic education teachers at the elementary school. It can be seen from the increasing in mastery of teaching materials, instructional planning, implementation of learning and assessment of learning outcomes. 2) The barriers experienced by supervisors in academic supervision in Islamic education is a lack of supervisory personnel, the number of teachers that should be supervised, the lack of intensity of supervision and the lack of competence development of supervisors in Islamic education. 3) The solution of these problems are the recruitment of new supervisors, increasing the intensity of supervision at classroom visits and increasing capacity-building programs of academic supervision for supervisors regularly and continuously.
\end{abstract}

Keyword : Effectivity of supervision, Supervisor, Islamic education

\begin{abstract}
Abstrak
Strategi supervisi akademik pengawas yang efektif dapat meningkatkan kompetensi profesional guru. Keterbatasan jumlah pengawas dan luasnya wilayah binaan merupakan persoalan dalam supervisi akademik. Penelitian ini bertujuan mengetahui: 1) efektivitas supervisi akademik pengawas dalam meningkatkan kompetensi profesional guru PAI SD di Kecamatan Tambun Selatan, 2) kendala yang dihadapi pengawas dalam melakukan supervisi akademik, dan solusi agar supervisi akademik pengawas dapat meningkatkan kompetensi profesional guru PAI SD di Kecamatan Tambun Selatan. Hasil penelitian menunjukkan bahwa: 1) supervisi akademik yang dilakukan pengawas Pendidikan Agama Islam cukup efektif dalam meningkatkan Kompetensi profesional guru PAI terlihat dari meningkatnya penguasaan materi bahan ajar, perencanaan pembelajaran, pelaksanaan pembelajaran dan penilaian hasil belajar. 2) Hambatan yang dialami pengawas dalam supervisi akademik adalah kurangnya tenaga pengawas PAI, banyaknya guru yang harus dibina, kurangnya intensitas supervisi dan kurangnya pengembangan kompetensi supervisi akademik pengawas PAI. 3) Solusi dari kendala tersebut adalah rekrutmen pengawas baru, peningkatan intensitas supervisi kunjungan kelas dan peningkatan program pembinaan kemampuan supervisi akademik pengawas secara berkala dan berkesinambungan.
\end{abstract}

Kata Kunci : Efektivitas supervisi, Pengawas, pendidikan Agama Islam

1. PENDAHULUAN

Perkembangan dari ilmu pengetahuan dan teknologi di era informasi dan komunikasi yang kian maju telah mempengaruhi kehidupan manusia di segala bidang tidak terkecuali di bidang pendidikan. Kemajuan tersebut menuntut adanya peningkatan kualitas belajar 
mengajar guna menunjang pencapaian tujuan pendidikan. Di satu sisi kemajuan tersebut mendorong semangat guru dan siswa untuk lebih dinamis dalam interaksi belajar mengajar demi mencapai prestasi yang lebih tinggi, pada sisi lain memunculkan berbagai dampak negatif terutama yang menyebabkan merosotnya kualitas belajar mengajar dan moral peserta didik (Hasbullah, 1996: 21).

Salah satu mata pelajaran yang terkena imbasnya adalah Pendidikan Agama Islam. Pendidikan Agama Islam (PAI) yang merupakan bagian dari penyelenggaraan pendidikan di Indonesia harus berbenah. Secara normatif Pendidikan Islam (PAI) di sekolah umum sebagai refleksi pemikiran pendidikan Islam, sosialisasi, internalisasi, dan rekontruksi pemahaman ajaran dan nilainilai Islam. Secara praksis PAI bertujuan mengembangkan kepribadian muslim yang memiliki kemampuan kognitif, afektif, normatif, dan psikomotorik, yang kemudian dalam cara berfikir, bersikap, dan bertindak dalam kehidupannya. Dengan pembelajaran PAI, siswa diharapkan mampu mengembangkan kepribadian sebagai muslim yang baik, menghayati dan mengamalkan ajaran serta nilai Islam termasuk menjauhi hal-hal yang dilarang dalam kehidupannya (Kurikulum PAI, 2002 : 3).
Sekolah adalah tempat berkumpulnya para siswa (Marpaung, 2021). Keberhasilan penyelenggaraan pendidikan agama Islam pada sekolah sangat terkait dengan keberhasilan peningkatan kompetensi dan profesionalisme pendidik dan tenaga kependidikan. Pengawas PAI pada sekolah merupakan salah satu pendidik dan tenaga kependidikan yang posisinya memegang peran yang sangat signifikan dan strategis dalam meningkatkan profesionalisme guru agama Islam dan mutu pendidikan. Peran pengawas PAI dalam melaksanakan tugas-tugas kependidikan dan pembelajaran di sekolah bukan saja sebagai seorang supervisor pendidikan, namun ia juga sebagai konselor dan motivator agar dapat menciptakan suasana kondusif dalam proses belajar mengajar di sekolah (Direktorat pendidikan Islam, 2012: ii).

Supervisi Pendidikan Agama Islam diarahkan pada dua sasaran pokok, yaitu supervisi terhadap kegiatan yang bersifat teknis edukatif dan teknis administratif. Supervisi teknis edukatif meliputi kurikulum, proses belajar- mengajar dan penilaian pendidikan agama. Sedangkan supervisi teknis administratif meliputi administrasi personal, administrasi material, administrasi keuangan, administrasi laboratorium dan 
perpustakaan sekolah (Depag RI: memberi pengarahan dan bimbingan 2003,75).

(Suharsimi Arikunto, 2004:76). Kalau

Kegiatan supervisi yang dilakukan oleh pengawas kepada guru-guru pengawas terus menerus mengarahkan selain tidak demokratis, juga tidak diharapkan dapat mewarnai pembelajaran. Semakin baik pelaksanaan supervisi dilaksanakan semakin baik pula pembelajaran di sekolah (Piet Sahertian, 2000: 91). Pertanyaan yang timbul adalah "sudahkah supervisi yang dilaksanakan pengawas berlangsung secara efektif? Supervisor yang efektif adalah selalu proaktif dalam memberikan pendekatan dan tanggungjawabnya, yaitu memiliki perencanaan ke depan, mengatasi masalah yang timbul dengan cara yang sesuai dengan jenis masalah yang dihadapi. Supervisor juga harus mengetahui, memahami serta melaksanakan teknikteknik dalam supervisi. Berbagai teknik dapat digunakan oleh pengawas dalam membantu guru meningkatkan situasi belajar mengajar, baik secara kelompok maupun secara perorangan ataupun dengan cara langsung bertatap muka dan cara tak langsung bertatap muka melalui media komunikasi (Syaiful Sagala, 2010:174).

Dalam iklim demokrasi harus ada reformasi unjuk kerja pengawas. Hal yang harus dirubah adalah unjuk kerja pengawas yang memakai pola lama yaitu mencari kesalahan dan kebiasaan memberi kesempatan guru-guru belajar berdiri sendiri (otonom) dalam arti profesional. Guru tidak diberi kesempatan untuk berdiri sendiri atas tanggungjawab sendiri padahal ciri dari guru yang profesional ialah guru-guru bebas dalam mengembangkan diri sendiri atas kesadaran diri sendiri.

Dalam Pelaksanaan pengawasan seringkali supervisi mengalami beberapa kendala. Hendiyat Soetopo dan Wasty Soemanto (1984: 62) mengindikasikan ada tiga hambatan dalam pelaksanaan pengawasan, pertama, faktor organisasi pengawas karena kurangnya pengenalan dan kesadaran tentang tanggungjawab pengawas serta kegagalan dalam menetapkan wewenang dan tanggungjawab pengawas. Kedua, di pihak pengawas, yang kurang dipersiapkan menjadi pengawas, pengalaman belajar yang pernah diperoleh di saat "preservice education" belum menjadi bekal yang cukup untuk melaksanakan tugas pengawasan. Kurangnya pengetahuan dan ketrampilan pengawas daripada kepala sekolah dan pemimpinpemimpin pendidikan lainnya, akan menghambat pelaksanaan pengawasan 
pendidikan. Ketiga, dari sikap guru-guru terhadap pengawas merupakan faktor penting dalam pelaksanaan pengawasan. Kesan guru terhadap pengawas yang kurang demokratis pernah terjadi di masa lalu. Karena hal inilah yang menjadikan pembinaan terhadap kemampuan profesional guru sangat diperlukan. Peningkatan kualitas mengajar guru dilakukan dengan berbagai upaya, antara lain melalui lembaga pre-service education, in-service education, dan onservice education. Pre-service education meliputi program diploma, sarjana, pascasarjana, dan lain-lain. Sedangkan inservice education meliputi in-service training seperti supervisi penataran dan lain-lain. Sedangkan on- service education seperti Kelompok Kerja Guru (Piet Sahertian dan Ida Alaida:1992:2).

Hasil penelitian menunjukkan bahwa sebagian guru yang telah lama melaksanakan tugas sebagai pengajar, menganggap pekerjaan mengajar sebagai kegiatan rutinitas. Metode pembelajaran yang digunakan miskin dengan variasi yang dapat mendorong peserta didiknya belajar lebih bergairah. Kondisi seperti ini dapat menyebabkan situasi belajar di kelas gersang dan membosankan, layanan belajar yang diterima peserta didik menjadi tidak bermutu (Sagala, 2011:171). Proses pembelajaran seperti ini akan menghasilkan lulusan dan sumberdaya manusia yang tidak bermutu, maka dampaknya adalah daya saing bangsa menjadi rendah dan kualitas kesejahteraan bangsa ini menjadi rendah pula.

Berbagai faktor penghambat peningkatan profesionalitas guru tersebut mengindikasikan bahwa guru perlu dibantu dalam meningkatkan kualitas profesionalnya agar dapat memberikan layanan belajar yang prima bagi peserta didik. Bantuan tersebut antara lain dapat dilakukan melalui upaya supervisi akademik pengawas sekolah yang dilakukan secara sungguh-sungguh, sistematis dan berkesinambungan.

Idealnya pengawas sekolah sebagai supervisor akademik harus menjadi idola para guru, karena keberadaan pengawas di tengah-tengah mereka menjadi inspirator bagi guru untuk mengatasi berbagai masalah yang berkaitan dengan tugas mengajar. Namun menurut Mukhtar dan Iskandar (2009: 39) pelaksanaan supervisi akademik oleh pengawas di sekolah belum efektif sehingga belum memberi kontribusi yang memadai untuk meningkatkan mutu layanan belajar, alasan utamanya bertumpu pada dua hal yaitu pertama beban kerja pengawas terlalu berat, kedua latar belakang pendidikan mereka kurang sesuai dengan 
bidang studi yang disupervisi. Akibatnya, di lapangan beberapa guru merasakan kehadiran pengawas di tengah-tengah mereka tidak dapat membantu memperbaiki dan mengatasi kesulitan guru dalam melaksanakan tugas dihadapinya.

Hasil wawancara penulis dengan guru-guru PAI SD di Kecamatan Tambun Selatan menunjukkan bahwa peran supervisi pengawas PAI dirasakan efektif dalam meningkatkan kompetensi profesional guru. Memang harus diakui bila selama ini intensitas kunjungan kelas pengawas ke sekolah-sekolah dirasakan kurang. Bimbingan yang dilakukan pengawas PAI lebih sering dilakukan pada forum KKG PAI. Namun demikian pembinaan yang dilakukan pengawas memberikan manfaat kepada guru-guru PAI di Kecamatan Tambun Selatan. Hal ini disampaikan oleh guru-guru PAI SD bahwa pembinaan yang dilakukan pengawas selama ini mampu meningkatkan kemampuan mengajar mereka. (Wawancara dengan GPAI, 27 April 2013)

Banyaknya jumlah sekolah yang menjadi binaan juga menjadi permasalahan tersendiri dalam pelaksanaan supervisi pendidikan. Lokasi yang luas karena sebagian besar pengawas PAI SD di Kabupaten Bekasi mempunyai wilayah binaan 130 sekolah yang terdiri dari 4 Kecamatan, termasuk di Tambun Selatan. Menurut Permenpan No. 21 Tahun 2010, idealnya beban kerja pengawas hanya 37,5 jam perminggu dan pengawas mengawasi 60 orang guru PAI SD. Keadaan ini menambah permasalahan pengawasan pendidikan Agama Islam khususnya di wilayah kerja Kecamatan Tambun Selatan.

Keterbatasan jumlah Pengawas dan luasnya wilayah binaan memang menjadi penghambat keberhasilan supervisi akademik. Namun hal tersebut bukan menjadi kendala ketika pengawas cerdas menggunakan strategi supervisi yang efektif. Hal lain yang dapat dilakukan pengawas adalah meningkatkan efektivitas supervisi akademik pengawas, penggunaan bantuan teknologi dalam supervisi dan pemberdayaan KKG PAI.

\section{Rumusan masalah}

Rumusan masalah penelitian tersebut dapat dirinci ke dalam beberapa pertanyaan penelitian sebagai berikut :

1. Bagaimana efektivitas pelaksanaan supervisi akademik yang dilakukan pengawas dalam meningkatkan kompetensi profesional guru PAI SD Kecamatan Tambun Selatan?

2. Apa kendala dan solusi pelaksanaan supervisi akademik yang dilakukan pengawas dalam meningkatkan 
kompetensi profesional guru PAI SD

Kecamatan Tambun Selatan?

\section{Tujuan Penelitian}

1. Efektivitas pelaksanaan supervisi akademik yang dilakukan pengawas dalam meningkatkan kompetensi profesional guru PAI SD di kecamatan Tambun Selatan.

2. Kendala dan solusi mengenai supervisi akademik pengawas PAI dalam meningkatkan kompetensi profesional Guru PAI SD di Kecamatan Tambun Selatan.

\section{Manfaat Penelitian}

\section{Manfaat Teoritis}

Secara akademis, temuan-temuan dalam penelitian ini dapat menjadi bahan untuk memperkaya konsep dan teori mengenai supervisi akademik pengawas. Indikator-indikator ketidakefektifan pelaksanaan supervisi akademik menjadi bahan kajian untuk diteliti lebih lanjut sehingga akan dihasilkan konsep acuan bagi kegiatan keilmuan dalam masalah supervisi akademik pengawas. Faktorfaktor yang menjadi kendala dan solusi pelaksanaan supervisi akademik menjadi bahan penelitian lebih lanjut terutama tingkat hubungan dan pengaruhnya terhadap supervisi akademik, sehingga akan diperoleh konsep yang turut memperkaya perbendaharaan supervisi akademik.

\section{Manfaat Praktis}

Secara praktis, temuan-temuan dalam penelitian ini, diharapkan dapat bermanfaat untuk kemajuan

Penyelenggaraan supervisi akademik pengawas khususnya di Kecamatan Tambun Selatan. Informasi dan kesimpulan hasil penelitian akan dijadikan dasar untuk memberikan masukan kepada para pengawas sekolah sebagai bahan rujukan dalam menyusun strategi supervisi akademik secara efektif.

Bagi birokrasi yang mengelola peningkatan mutu pendidikan diharapkan indikator dan faktor-faktor yang menghambat efektivitas pelaksanaan supervisi akademik dapat menjadi bahan pertimbangan dalam pembuatan kebijakan pendidikan khusususnya di bidang kepengawasan.

Bagi profesi pengawas, pelaksanaan supervisi dan kendala yang ditemukan sebagai sumbangan pemikiran, koreksi dan refleksi dalam meningkatkan kinerja sesuai dengan peran, tanggungjawab dan tupoksi pengawas, khususnya dalam menjalankan tugas supervisi akademik ke sekolah-sekolah binaan.

Seperti yang telah diuraikan sebelumnya bahwa penelitian ini bertujuan ingin mengetahui efektivitas pelaksanaan supervisi akademik pengawas PAI dalam meningkatkan kompetensi profesional 
guru PAI SD di Kecamatan Tambun

Selatan. Terkait dengan hal tersebut, pada sub bab ini akan diuraikan mengenai teoriteori Efektivitas, supervisi akademik, pengawas PAI dan kompetensi profesional guru, yang selanjutnya penulis jadikan landasan atau acuan dalam melakukan penelitian.

\section{Efektivitas}

Efektivitas mempunyai arti yang berbeda-beda bagi setiap orang, tergantung pada kerangka acuan yang dipakainya. Efektif ialah tingkat keberhasilan pencapaian tujuan (outcomes) dengan cara melakukan pekerjaan yang benar (do the right things). Efektif juga berarti mampu mencapai tujuan dengan baik. Jika efisiensi lebih memfokuskan diri pada proses penghematan, maka keefektifan (effectiveness) lebih memfokuskan diri pada output atau hasil yang diharapkan. Hasil yang diharapkan dapat diukur secara kuantitatif dan kualitatif.

Efektif ialah cara melakukan sesuatu (pekerjaan) yang benar (do the right things), sedangkan efisiensi (daya guna) ialah cara melakukan pekerjaan dengan benar (do things right). Efektif dapat ditinjau dari sudut kuantitatif dan kualitatif. Pengertian efektif secara kuantitatif ialah perbandingan antara realisasi dengan target. Semakin tinggi realisasi yang dicapai, semakin tinggi nilai efektifnya. Efektif menurut pengertian kualitatif ialah tingkat pencapaian tujuan atau tingkat kepuasan yang dicapai. Semakin tercapai tujuan seseorang atau organisasi semakin efektif seseorang atau organisasi itu. Semakin puas seseorang atau organisasi, semakin efektif seseorang atau organisasi itu. Kepuasan meliputi kepuasan internal dan eksternal organisasi (Husaini Usman, 2010: 44).

Dalam Perilaku Organisasi untuk memahami makna atau konsep Efektivitas dikenal tiga pendekatan, yakni: pendekatan tujuan atau disebut the goal optimization approach, pendekatan sistem atau dikenal the system theory approach dan pendekatan kepuasan partisipasi atau disebut participant satisfaction model (Gibson, 1998:98).

Efektivitas adalah pemanfaatan sumber daya, sarana dan prasarana dalam jumlah tertentu yang ditetapkan sebelumnya untuk menghasilkan sejumlah sesuatu atas jasa kegiatan yang dijalankannya. Efektivitas menunjukan keberhasilan dari segi tercapai tidaknya sasaran yang telah ditetapkan. Jika hasil kegiatan semakin mendekati sasaran, berarti makin tinggi efektivitasnya (Siagian, 2001: 24).

Efektivitas menunjukkan kemampuan dalam mencapai sasaran yang telah ditetapkan secara tepat. Pencapaian 
sasaran yang telah ditetapkan dan ukuran maupun standar yang berlaku mencerminkan supervisi akademik berjalan efektif. Terdapat beberapa cara pengukuran terhadap efektivitas, sebagai berikut: menurut Gibson et, al (Usman, 2010:3) menyatakan bahwa efektivitas dapat dilihat dari perspektif: effektivitas individual (input), efektivitas kelompok (proses), efektivitas organisasi. Efektivitas individual ditentukan oleh pengetahuan, sikap, ketrampilan, kemampuan, motivasi dan stress. Efektivitas kelompok ditentukan oleh kekompakan (achieveness), kepemimpinan, struktur, status, peran dan norma. Efektivitas organisasi ditentukan oleh lingkungan, tehnologi, pilahan strategis, struktur dan budaya.

Cowan dalam Sukadi (2002:12) mengemukakan bahwa efektivitas dihubungkan dengan pencapaian sasaran yang telah ditentukan atau perbandingan antara hasil nyata dengan hasil ideal. Sedangkan Hadari Nawawi (1984:43) menjelaskan bahwa efektivitas maksudnya adalah menilai tindakan atau kegiatan yang telah dilakukan apakah telah menghasilkan sesuatu seperti yang direncanakan dan berjalan dengan sebenarnya serta tidak menyimpang dari perencanaan sehingga sesuai dengan tujuan yang harapkan.
Berdasarkan uraian tersebut, maka dapat disimpulkan bahwa efektivitas adalah tingkat pencapaian tujuan atau sasaran organisasional sesuai yang ditetapkan. Efektivitas adalah seberapa baik pekerjaan yang dilakukan dan sejauh mana supervisi menghasilkan tujuan sesuai dengan yang diharapkan. Ini dapat diartikan, apabila sesuatu pekerjaan dapat dilakukan dengan baik sesuai dengan yang direncanakan. Oleh karena itu, dalam menentukan Efektivitas supervisi akademik pada penelitian ini, dapat diukur melalui indikator sebagai berikut :
a. Keberhasilan program
b. Keberhasilan sasaran
c. Tingkat input dan output

\section{Supervisi Akademik}

Supervisi akademik merupakan bagian dari supervisi pendidikan yang menitikberatkan pada upaya memberi bantuan meningkatkan mutu pembelajaran dan profesional guru sebagai pengelola proses belajar mengajar di kelas.

Menurut Muslim (2010: supervisi akademik adalah serangkaian usaha pemberian bantuan kepada guru dalam bentuk layanan profesional yang diberikan oleh supervisor (kepala sekolah, penilik sekolah dan pembina lainnya) guna meningkatkan mutu proses dan hasil belajar mengajar". Sementara itu Neagley dan Evans (1980: 20) 
menyatakan bahwa "supervision isconsidered as any service for teachers that eventually result in improvinginstruction, learning, and the curriculum".

Boardmab dalam Arikunto (2006: 12), menyatakan bahwa supervisi akademik bukan hanya membantu guru dalam memahami pendidikan dan apa peran sekolah dalam mencapai tujuannya, tapi juga membantu guru dalam memahami keadaan dan kebutuhan siswanya, sebagai dasar analisis dalam menyusun rencana pembelajaran secara tepat. Disamping itu, supervisi membantu guru agar memiliki kemampuan dalam mengembangkan kecakapan pribadi.

Supervisi juga bertujuan membentuk moral kelompok yang kuat dan mempersatukan guru dalam satu tim yang efektif, bekerjasama secara akrab dan bersahabat serta saling menghargai satu sama lainnya. Makna lain yang terkandung dalam definisi tersebut adalah bahwa supervisi dimaksudkan untuk membantu guru dalam memberi pengertian kepada masyarakat mengenai program yang sudah ada dan direncanakan oleh sekolah agar masyarakat dapat mengerti dan membantu usaha sekolah. Intinya, supervisi akademik menurut Bordmab adalah bantuan kepada guru dalam meningkatkan pemahaman dan kecakapan kompetensi profesional tenaga pendidik, agar berhasil mencapai tujuan pendidikan. (Arikunto:2006:14).

$$
\text { Menurut Mulyasa }
$$
supervisi akademik merupakan suatu proses yang dirancang secara khusus untuk membantu guru meningkatkan pengetahuannya dan kemampuannya untuk memberikan layanan yang lebih baik pada orang tua, peserta didik dan sekolah serta berupaya menjadikan sekolah sebagai masyarakat belajar yang efektif.

Berdasarkan beberapa rumusan pengertian supervisi akademik dari para pakar tersebut di atas, dapat disimpulkan bahwa pengertian supervisi akademik adalah kegiatan berupa bantuan dan bimbingan yang diberikan oleh supervisor, yaitu pengawas sekolah dan kepala sekolah kepada guru dalam meningkatkan kinerjanya dan kemampuan pengelolaan pembelajaran sehingga akan mendorong peningkatan prestasi belajar peserta didik yang pada akhirnya dapat meningkatkan mutu Pendidikan.

\section{METODE PENELITIAN}

Penelitian ini menggunakan pendekatan penelitian kualitatif. Penelitian ini memahami efektivitas pelaksanaan supervisi akademis pengawas dalam meningkatkan kompetensi 
profesional guru PAI. Pendekatan kualitatif adalah penelitian yang menghasilkan prosedur analisis yang tidak menggunakan prosedur analisis statistik atau cara kuantifikasi lainnya. ( Moleong, 2005: 31). Menurut Masyhuri dan M. Zainuddin (2008:13 ) kualitatif adalah penelitian yang pemecahan masalahnya dengan menggunakan data empiris. Penelitian kualitatif membutuhkan studi mendalam untuk membentuk suatu model atau teori berdasarkan adanya keterkaitan antara data yang ditemukan.

Pendekatan kualitatif dipilih dalam penelitian ini karena beberapa pertimbangan antara lain: (1) data yang digunakan. Dalam penelitian ini lebih mengarah pada data-data yang bersifat verbal dan perilaku subyek peneliti yaitu analisis yang berhubungan dengan supervisi akademik yang dilakukan pengawas Pendidikan Agama Islam di Kecamatan Tambun Selatan dalam meningkatkan kompetensi profesional guru, (2) berdasarkan jenis data yang akan dikumpulkan dalam penelitian ini, yaitu yang berhubungan dengan situasi dan kondisi pengawas PAI di lapangan, (3) dan analisis data yang digunakan ialah model analisis langsung dan mempunyai hubungan yang saling berkaitan antara tema pembahasan satu dengan pembahasan lain, (4) hasil penelitian yang berupa kesimpulan yang diperoleh setelah diadakan analisis data dinyatakan dalam deskripsi situasi dan bukan perhitungan angka model statistik, (5) penelitian ini dilakukan dalam situasi yang wajar dan mengutamakan data yang bersifat kualitatif.

\section{PEMBAHASAN}

Pengawas memerlukan strategi dan cara khusus untuk melakukan supervisi dalam rangka membantu guru menyelesaikan masalah-masalah dalam pelaksanaan kegiatan pembelajaran. Strategi yang diterapkan pengawas dalam hal ini tidak bisa dilepaskan dari tipe-tipe guru. Tipe-tipe tersebut adalah:

a) Jika kemampuan berpikir abstrak tinggi dan komitmen serta kepedulian juga tinggi, maka termasuk guru professional

b) Jika kemampuan berpikir abstrak tinggi dan komitmen serta kepedulian rendah maka disebut guru tukang kritik.

c) Jika kemampuan berpikir abstrak rendah sedangkan komitmen serta kepedulian tinggi maka disebut guru terlalu sibuk.

d) Jika kemampuan berpikir abstrak rendah dan komitmen serta kepedulian juga rendah maka disebut guru yang tidak bermutu. 
Untuk mengatasi guru dengan berbagai tipikalnya, maka pengawas menerapkan 3 strategi supervisi PAI, yaitu dengan supervisi langsung, tidak langsung dan kolaboratif. Pertama, supervisi pengajaran berorientasi langsung. Supervisi ini akan mencakup perilaku pokok berupa klarifikasi, prestasi, demonstrasi, penegasan, standarisasi, dan penguatan. Hasil akhir dari perilaku supervisi pengajaran ini adalah tugas bagi guru yang harus dikerjakan dalam satu periode waktu tertentu. Asumsi yang mendasari orientasi ini sama halnya dengan asumsi dasar psikologi perilaku, bahwa mengajar itu pada dasarnya merupakan pengkondisian individu melalui lingkungannya. Dalam mengadakan supervisi langsung, pengawas melakukan lima perilaku supervisor, yaitu:

1) mengklarifikasi masalah-masalah guru, baik melalui pertemun $\mathrm{KKG}$ PAI

2) mempresentasikan ide-ide pemecahan masalah;

3) Mendemonstrasikan, sebagai contoh, ide-ide pemecahan masalah yang harus dilakukan oleh guru, sebagai tugas guru;

4) menetapkan standar pelaksanaan tugas pemecahan masalah;
5) memberikan reinforcement kepada guru agar ia melaksanakan tugas yang diberikan.

Berdasarkan hasil wawancara dengan pengawas dan pengamatan terhadap jalannya proses supervisi yang dilakukan pengawas, diketahui bahwa teknik-teknik supervisi yang diterapkan pengawas cukup bervariasi. Dilihat dari pendekatannya, pengawas dalam melakukan kegiatan supervisi menerapkan tiga model pendekatan, yakni menggunakan pendekatan kedinasan, pendekatan sebagai mitra kerja, dan pendekatan secara kekeluargaan.

Sedangkan dilihat dari teknik yang diterapkannya, pengawas dapat menerapkan atau melaksanakan kegiatan supervisi dengan teknik-teknik yang cukup bervariasi. Teknik-teknik kegiatan supervisi pengawas yang dapat diidentifikasi antara lain; teknik diskusi kelompok atau rapat supervisi, teknik pertemuan individual, dan teknik kunjungan kelas. Keadaan ini menunjukan bahwa pengawas telah memiliki keterampilan yang cukup baik dalam melakukan supervisi akademik. Dengan demikian, keterampilan yang dimiliki pengawas tersebut merupakan salah satu kekuatan yang dimiliki Kementerian agama kabupaten Bekasi dalam rangka meningkatkan kemampuan 
profesional guru dalam hal mengelola KBM, sehingga pada gilirannya dapat pula meningkatkan mutu proses dan hasil pembelajaran.

Teknik supervisi yang digunakan pengawas sebagaimana tersebut di atas, pada tataran implementasi untuk teknikteknik tersebut tidak semuanya dapat dilaksanakan dengan baik, hal ini sebagaimana penjelasan pengawas ketika diadakan wawancara, serta hasil pengamatan yang dilakukan terhadap jalannya kegiatan supervisi yang dilakukan oleh pengawas. Dari hasil wawancara dan pengamatan yang dilakukan, dapat diidentifikasi dua hal kaitannya dengan penerapan teknik-teknik supervisi pengawas. Pertama untuk kepentingan apa teknik tersebut digunakan, dan kedua bagaimana teknik tersebut diterapkan.

Teknik diskusi kelompok supervisi secara umum digunakan dalam rangka merumuskan atau menyusun materi dan jenis program yang akan disupervisi, mendiskusikan hasil supervisi, mendiskusikan rencana tindak dalam memecahkan permasalahan, dan dilaksanakan untuk menghitung ketercapaian suatu program. Teknik diskusi kelompok dilakukan melalui pendekatan diskusi terbatas, yakni kegiatan diskusi yang dilaksanakan antara pengawas dengan guru-guru PAI yang menjadi pengurus KKG PAI Kecamatan Tambun Selatan. Selanjutnya hasil diskusi menjadi acuan bagi pembinaan pengawas yang dilakukan dalam forum KKG PAI Kecamatan Tambun Selatan (wawancara dengan pengawas tanggal 21 Januari 2017).

Pertemuan individual menurut keterangan pengawas, digunakan dalam rangka membimbing guru dalam memecahkan permasalahan, dan mendorong guru meningkatkan kemampuan profesionalnya. Pembicaraan individu dalam prosesnya menekankan pada hubungan keakraban antara pengawas dengan guru yang disupervisi. Interaksi yang terjadi diantara keduanya adalah interaksi hubungan kesejawatan ataupun rekan/mitra kerja yang samasama memiliki tanggungjawab untuk meningkatkan mutu proses dan hasil pembelajaran. Suasana keakraban pada kegiatan supervisi yang diciptakan oleh pengawas melalui teknik pembicaraan individual seperti ini, tentu saja sangat kondusif bagi upaya penggalian berbagai persoalan ataupun kendala yang dihadapi guru selama menjalankan tugasnya, yang pada akhirnya secara bersamasama melakukan atau mencari penanganan kendala atau masalah tersebut. 


\section{PENUTUP}

\section{Simpulan}

\begin{tabular}{|c|c|c|}
\hline Kesimp & yang & dapat \\
\hline dikemukakan & berkenaan & dengan \\
\hline efektivitas & pelaksanaan & supervisi \\
\hline akademik pen & gawas dalam m & ingk \\
\hline kompetensi & profesional $\mathrm{g}$ & adalal \\
\hline
\end{tabular}

1. Efektivitas pelaksanaan supervisi akademik pengawas PAI di kecamatan dalam meningkatkan kompetensi profesional guru PAI dilakukan dengan peningkatan kemampuan guru dalam penguasaan materi ajar, merencanakan kegiatan pembelajaran, pelaksanaan pembelajaran dan penilaian hasil pembelajaran. Strategi dan pendekatan supervisi akademik pengawas PAI dalam meningkatkan kompetensi profesional guru yang efektif diantaranya dilakukan dengan menciptakan hubungan yang harmonis antar pengawas dan kepala sekolah dalam berbagi peran melakukan supervisi guru dan kerjasama dengan pengurus kegiatan KKG PAI dalam merumuskan program-program kerja yang sangat dibutuhkan guru dalam meningkatkan kemampuan profesionalnya.

2. Kendala pengawas dalam supervisi akademik di kecamatan Tambun
Selatan adalah: jumlah sekolah dan guru binaan yang terlalu banyak, intensitas supervisi kelas yang kurang dan belum optimalnya pengembangan kompetensi supervisi akademik pengawas PAI.

Untuk mengatasi kendala tersebut, maka solusi yang dilakukan agar pelaksanaan supervisi akademik pengawas dapat lebih efektif dalam meningkatkan kompetensi profesional guru adalah: rekrutmen dan pengangkatan pengawas baru oleh Kementerian Agama, pengawas perlu melakukan supervisi akademik yang lebih intens, meningkatkan pembinaan terhadap pengawas melalui monitoring dan evaluasi terhadap perencanaan dan pelaksanaan program yang dilakukan pengawas secara berkala dan perlu diterapkan sistem reward and punishment yang jelas dan memprogramkan secara rutin kegiatankegiatan yang dapat menunjang peningkatan kompetensi pengawas, terutama yang berkaitan dengan kompetensi akademik pengawas.

\section{Saran}

Berdasarkan kesimpulan di atas, maka disampaikan beberapa saran sebagai berikut :

1. Bagi pengawas:

Meningkatkan $\quad$ frekuensi
kunjungan baik secara kualitas 
maupun kuantitas untuk melakukan supervisi akademik kepada guru yang sudah disertifikasi maupun yang belum disertifikasi (PNS maupun honorer) secara kontinu dan berkesinambungan.

b) Meningkatkan efektivitas pelaksanaan supervisi akademik dengan menerapkan prinsipprinsip, pendekatan serta teknik yang tepat sesuai perencanaan lengkap dengan dokumentasinya.

c) Meningkatkan efektivitas tindak lanjut supervisi akademik dengan melakukan kegiatan analisis dan evaluasi, pelaporan serta tindak lanjut supervisi akademik lengkap dengan dokumentasinya.

d) Meningkatkan partisipasi aktif dalam kegiatan KKKS dan KKG sebagai wadah pembinaan profesi dan peningkatan mutu pendidikan.

2. Bagi Kementerian Agama:

a) Hendaknya menambah tenaga kepengawasan, karena tenaga kepengawasan harus sesuai dengan jumlah sekolah dan guru binaan sehingga akan menghasilkan mutu pendidikan yang semakin baik

b) Meningkatkan pembinaan keprofesian berkelanjutan bagi pengawas.
Penelitian ini hanya memfokuskan pada pelaksanaan supervisi akademik pengawas PAI yang efektif di tengah keterbatasan jumlah pengawas dan banyaknya sekolah binaan dalam meningkatkan kompetensi profesional guru. Kompetensi profesional guru yang diteliti hanya dalam pembelajaran baik penguasaan materi ajar, perencanan pembelajaran, pelaksanaan dan penilaian pembelajaran sehingga belum menggambarkan peningkatan kompetensi profesional guru secara menyeluruh. Masih perlu adanya penelitian lanjut agar dapat mengungkap lebih dalam tentang langkah-langkah supervisi akademik, strategi peningkatan kompetensi guru dalam kompetensi profesional penguasaan IT maupun pembuatan karya ilmiah.

\section{REFERENSI}

Alma, Buchari. (2010). Guru Profesional Menguasai Metode dan Terampil Mengajar. Bandung: Alfabeta

Arikunto, S. (2006). Dasar-Dasar Supervisi. Jakarta:Rineka Cipta , (2009). Metode Penelitian. Bandung:Alfabeta

Atmodiwiryo, Soebagio. (2011). Manajemen Pengawasan dan Supervisi Sekolah. Jakarta: PT. Ardadizya jaya.

Cholid Narbuko dan Abu Achmadi. (2005), Metodologi Penelitian, 
Jakarta: Bumi Aksara

Departemen Agama RI.( 1999). Petunjuk Teknis Pelaksanaan Jabatan Fungsional Pengawas Pendidikan Agama Islam dan Angka Kreditnya, Jakarta: Direktorat Jendral Kelembagaan Agama Islam.

Departemen Agama RI. (2003). Kendali Mutu Pendidikan Agama Islam,Jakarta: Direktorat Jendral Kelembagaan Agama Islam.

Gibson, (1998), Organisasi, Alih bahasa Nunik Adriani, Jakarta : Bina rupa aksara)

Glickman, Carl. D. (1981). Developmental Supervision: Alternative Practice for

Helping Teacherss Improve Instruction. Alexandria: ASCD

Gwin, John Minor. (1965). Theory and Practise of Supervision. Dod, New

York:Mead and Company

Hadari Nawawi, (1984). Dasar-dasar Kependidikan. Jakarta: Depdikbud Dirjen Dikti P2LPTK

Hamidi, (2008). Penelitian Kualitatif: Pendekatan Praktis Penulisan Proposal dan Penelitian, Malang: Universitas Muhammadiyah Malang Press.

Hanun Asrohah. Modul Manajemen Sekolah Efektif. ( Surabaya: Tidak diterbitkan. 2010)

Hubermen, (1992), Qualitative data Analysis. Saga Publication. Beverly Hills and London

Husaini Usman (2010). Manajemen, teori, Praktek dan Riset Pendidikan. Jakarta: Bumi Aksara
Marpaung, N. N. (2021). Implementation of Online Learning Applications in SD Bina Kreasi Mandiri Bekasi : Infrastructure Effect Analysis. 2019(December 2019), 1796-1807. 